\title{
KNOW YOUR WORTH: ANGEL FINANCING OF FEMALE ENTREPRENEURIAL VENTURES ${ }^{1}$
}

\author{
Honors Thesis \\ Presented to the College of Agriculture and Life Sciences, Applied Economics and Management \\ of Cornell University \\ in Partial Fulfillment of the Requirements for the \\ Research Honors Program \\ by \\ Melanie R. Shapsis \\ May 2016 \\ Advisor: \\ Professor Sharon L. Poczter
}

${ }^{1}$ The author gratefully acknowledges the research assistance of Nikki B. Goldberg and six undergraduate research
assistants from the Charles H. Dyson School of Applied Economics and Management. The author would also like to
thank Professor Sharon L. Poczter for the invaluable advice and guidance provided throughout the entire process. 


\begin{abstract}
This study explores success rates in obtaining angel financing based on the gender composition of entrepreneurial teams using data from the television program Shark Tank. Consistent with prior work, we find that women-owned teams receive lower company valuations and less capital to finance their new ventures relative to their male counterparts. However, we find that the likelihood of a team receiving an offer from an angel investor is independent of the entrepreneurs' gender. We discover women-owned firms initially value their companies at significantly lower amounts than teams consisting of all males. Thus, angel investors provide lower final company valuations to women-owned firms because women, on average, ask for less. These results hold when controlling for important entrepreneur and firm characteristics that may strongly impact the angel financing outcome, such as the size of the entrepreneurial team, company age and prior success of the firm. We also find that the negative effect of a womenowned firm on the amount of financing received is highly dependent upon the industry the entrepreneurs choose to enter.
\end{abstract}

JEL Classification: J15, L26, M13

Key words: angel financing, gender differences, female entrepreneurship, women-owned firms, start-up capital 


\section{Introduction}

Women remain substantially underrepresented among entrepreneurs, yet women-owned businesses $^{2}$ represent the fastest growing sector of new venture ownership in the United States ("U.S.”) (Becker-Blease \& Sohl, 2007). According to data from the U.S. Census Bureau, from 1997 to 2012, women-owned firms grew at a rate of 2.5 times the national average; in the same time period, the number of business in the U.S. grew by $33 \%$, while U.S. women-owned firms increased by $82 \%$, as shown in Table 1 (U.S. Census Bureau, 1997-2012). Further, revenue and employment growth among women-owned firms outperformed that of all other firms, aside from large publically traded corporations (Coleman \& Robb, 2009). Even though women-owned firms are engines of economic growth, fewer women start companies each year. According to the 2015 Kauffman Index of Start-up Activity, in 1996, the rate of new male entrepreneurs ${ }^{3}$ who founded a company was $4.56 \%$ for the year, while the rate of new female entrepreneurs was $3.12 \%$. However, that rate further declined in 2014 , standing at $2.64 \%$ for the rate of new female entrepreneurs, as opposed to $4.92 \%$ for the rate of new male entrepreneurs (Fairlie, Morelix, Reedy, \& Russell, 2015). Additionally, out of the total new U.S. entrepreneurial population in $1996,56 \%$ were males and $44 \%$ were females, while in 2014 , the population consisted of $63 \%$ males and $37 \%$ females. Therefore, in the 18 -year span, the rate of new female entrepreneurs who started companies decreased, while the new male entrepreneurial population increased, thus making the space even more male-dominated.

\section{Insert Table 1 here}

\footnotetext{
${ }^{2}$ A firm is considered to be "women-owned" or "female-owned" if women own 51 percent or more of the equity, interest, or stock of the business.

${ }^{3}$ Rate of new entrepreneurs measures the percentage of the adult, non-business-owner population that starts a business
} 
The underrepresentation of female entrepreneurs and decrease in female start-up activity may be caused by a lack of financing. External financing from investors is crucial for the survival and growth in the early stages of a company (Amit, Glosten, \& Muller, 1990; Berger \& Udell, 1998). An especially important funding source for early-stage companies is angel financing because angel investors are more likely to invest in the risky stages of company development than are venture capital funds (Preston, 2004). Angel investors are generally high net worth individuals who invest in small, private firms on their own account (Wong, Bhatia, \& Freeman, 2009). Over the last 30 years, the level of investments made by angels has been double that of investments made by venture capitalists (Preston, 2004). Yet, prior literature suggests that women obtain significantly less capital to finance their new businesses (Alsos, Isaksen, \& Ljunggren, 2006).

This study seeks to understand the determinants of success in angel financing by female entrepreneurial ventures and disentangle whether gender matters separate from other characteristics that determine investment desirability. The unique hand-collected dataset allows for us to examine specific entrepreneur and firm characteristics in order to further isolate the underlying cause for the funding differences between teams. Thus, this allows us to get towards the gender bias. The main question underlying this investigation is: are women less likely to secure angel financing simply because of their gender alone? If women choose industries that may be of lower growth, or women-owned ventures are less successful prior to seeking funding, then the net present value ("NPV") of these firms should be lower, outside of any consideration of gender. This could make it harder to obtain financing. However, if women-owned ventures receive less funding in high growth industries with substantial prior company success, this would 
suggest a market imperfection such that positive NPV ventures are not funded merely because of a gender bias in investment.

Understanding the reasons behind differences in funding for male- and female-led companies has numerous implications for both entrepreneurs and policy. For entrepreneurs, it helps inform female start-ups how to better access vital funding for their new ventures. Further, it is crucial to understand whether an entrepreneur's gender may impact funding decisions for reasons outside of the potential success of the company. From a policy standpoint, addressing the central question as to whether gender bias exists in angel financing can inform governments the steps needed to take in order to remedy such issues. Female-owned firms make significant contributions to creating and maintaining a healthy and nimble national economy (U.S. Department of Commerce, 2010). They have grown in number and size over the past two decades, but are still far away from achieving parity with male-owned firms. Our results provide support for the importance of such government programs that can work to minimize the funding gap between all-female and all-male entrepreneurial ventures. The disparity in company valuations for all-female and all-male teams can also be dependent upon the industry the entrepreneurs choose to enter. Females may cluster in certain industries that may be of lower growth as this is where they believe they will have the highest chance of receiving funding. Thus, one potential governmental method to stimulate the financing of women-owned, and also women-owned firms in certain industries, is to provide tax incentives for companies that fund women-owned firms and firms in those industries. For instance, the government can provide either benchmark requirements for investors on the number of women-owned companies they need to fund, or the total magnitude of capital given to fund new female ventures. 
In this paper, we compare several measures of angel financing success based the gender composition of teams to understand why women-owned firms face funding difficulties. We use data collected from the television program Shark Tank, which provides many advantages. First, to the best of our knowledge, this is one of the first studies to examine companies that were both successful in securing angel financing and those that were not. Second, we take into consideration the entrepreneurs' initial company valuations ("initial company valuation") they come in requesting from investors, alongside the final company valuations ("final company valuation") they receive from the angel investors. We find that women are no less likely than men to obtain angel financing, yet the amount of capital female entrepreneurs obtain is significantly less than that of men. However, we find that the disparity in capital obtained is not due to differences in characteristics that can impact funding success, such as total company sales, total number of entrepreneurs on the team, company age, or personal capital invested into the business. But rather, our findings show that industry is important in understanding the company valuation differences based on gender. Dependent upon industry, women-owned firms receive lower final company valuations. Further, all-female teams, on average, ask for half the dollar amount than that of all-male teams and are willing to give up larger equity stakes in the company. Thus, women receive less capital; however, it is because they value their company at lower amounts, all else equal. Similar to the traditional angel financing route, firms present initial company valuations to investors, and our findings show that women-owned firms consistently undervalue themselves relative to their male counterparts. Therefore, limitations to angel financing are self-imposed.

Given the structure of our analysis and data collection, we are able to observe not only the final funding received, but also the potential failures and negotiation processes. The ability to 
view and incorporate these failures into analyses is very rarely used in prior literature. The former alleviates selection bias, while the latter allows us to include more nuanced metrics of success, such as the total number of offers a team received throughout the entire process. Prior studies have only had access to the final offer accepted by the entrepreneurs and were unable to track the number of different offers received by the team. Further, these interactions allow us to gather demographic, financial and commonality information in order to examine the antecedents of angel funding including gender, industry and negotiation processes.

\section{Literature Review}

This paper helps to understand fundamental gender differences in angel financing success rates by determining the underlying causes to the gaps in securing funding. Previous work has looked into the relationships between financing and gender, but has largely examined them in the context of bank loans (Buttner \& Rosen, 1989, 1992; Coleman, 2000; Fay \& Williams, 1993), and venture capital (Brush, Carter, Gatewood, Greene, \& Hart, 2004; Greene, Brush, Hart, \& Saparito, 2001). Brush, Carter, Gatewood, Greene, and Hart (2004) found that women have received a disproportionately low share of available venture capital in the U.S., and linked this to the fact that the majority of venture capitalists and important decision makers in venture capital firms are males. Yet, little work examines angel financing for women, even though this source of financing has been a crucial part of the success for female-lead start-ups relative to other sources such as venture capital (Gundry \& Welsch, 2001).

While closest in spirit to (Becker-Blease \& Sohl, 2007), data limitations prevent them from analyzing individual angel investing deals. Becker-Blease and Sohl (2007) use survey data to evaluate the proportion of total angel investment deals that go to women and the frequency with which the females seeking angel funding. However, without any specific knowledge of the 
characteristics of the individual financing deals, the determinants of deal success and size outside of gender, such as the initial success of the company, industry, or other control variables, cannot be understood. These variables are necessary to determine whether gender differences in funding stem from firm-level traits that determine value, or the gender of entrepreneurs alone. Thus, prior work determines patterns in angel financing, but not its antecedents. Other work examining the relationship between gender and the success of angel funding do not include failed pitches, and only examine those companies that were successfully funded (Coleman \& Robb, 2009; Fairlie \& Robb, 2009). Further, past studies do not have access to the variables we provide that we believe may strongly impact the financing decision, such as previous success measures of the firm or the size of entrepreneurial teams (Brooks, Huang, Kearney, \& Murray, 2014).

Additionally, past research does not consider differences in valuation, even though all entrepreneurs present their initial company valuations, comprised of an asking dollar amount and equity stake, to the angel investors. The prior datasets are limited to only analyzing final company valuations based on the funding entrepreneurs received, but do not consider the initial company valuations the entrepreneurs presented to the angel investors. This suggests that female entrepreneurs may not be less successful in obtaining funding, but rather may undervalue their companies relative to male counterparts. Given that the amount of funding new ventures receive will determine the capital adequacy of those ventures, and not only the likelihood of receiving funding, understanding gender differences in valuation as well will provide insight into the phenomenon that female-lead entrepreneurial ventures are underrepresented.

\section{Setting and Data}

We explore the relationship between gender and angel investment using hand-collected data from the television program Shark Tank. Beginning in 2009, this program features a panel 
of five angel investors who consider pitches from entrepreneurs (either alone or in a team) seeking financing. Every episode of the show consists of four separate pitches ${ }^{4}$ by different entrepreneurs. The structure of each pitch is as follows: the entrepreneur(s) present information regarding their company and investment goal, including the dollar value sought and equity stake offered. A question and answer period follows, during which the potential investors ask questions related to the company, product, entrepreneur(s), etc. This may include information covering the entrepreneur's work history, age of the company, amount of personal capital invested into the business, intellectual property rights, prior sales of the company, product production costs and selling prices. Finally, the investors may make offers and negotiate with the entrepreneurs over the equity stake $\mathrm{s}^{5}$ and a deal between the entrepreneur(s) and one or more angel investors may result. ${ }^{6}$

Altogether, the discussions between the investors and entrepreneurs reveal a great deal about each company. Using master spreadsheets, over 110 variables were collected from the video recordings of each pitch. All inputs for each variable were double keyed by two separate research assistants. The two datasets were then compared against one another to highlight any discrepancies. Following the identification of discrepancies, a third party reconciled all of the coding inconsistencies to improve data accuracy and minimize potential for human error. We then compiled a finalized, cleaned dataset after the three rounds of data collection.

\footnotetext{
${ }^{4}$ Eight episodes in Season 1 consisted of five separate pitches, as opposed to the standard four pitches.

${ }^{5}$ The show operates under one main rule regarding the investment: entrepreneur(s) must obtain at least the dollar value offered in order to obtain a deal. From one perspective, this is a drawback as it may not be reflective of traditional angel investment, since entrepreneurs can negotiate down the dollar value asked and still receive investment. However, from a research perspective, this is advantageous as it essentially holds constant the dollar amount. This enables us to conclude that changes from asking valuation to accepted valuation are a function not of the absolute value of the dollar amount asked, but rather changes in equity.

${ }^{6}$ More details on the selection process for the television program can be found in Appendix A.
} 
As we are interested in the relationship between gender and success in angel investment, several different measures of angel financing success were collected. Thus, we focus our analysis on the following variables. We first consider whether entrepreneurial teams received an offer at all, or the intensive margin. This variable, "offer", is an indicator equal to one for those pitches that received at least one offer from the investors and zero for no offers. We are also interested in understanding the relationship between gender and final company valuations. Therefore, final company valuations were calculated for teams that accepted an offer. The final company valuations are the quotient of the accepted dollar amount and the accepted equity amount. Given the final company valuation, another metric we examined is the difference between accepted final company valuation with the investors and the initial company valuation the entrepreneur presented ("bid ask spread").

Additionally, we are also interested in the descriptive information and firm characteristics that may help determine success. These include information regarding the company or product such as the industry, age of the company, location, product production costs and selling prices. We also examine financial information including the total company sales to date, debt taken out, personal capital invested, the number of existing investors, etc. Finally, data on the various company valuations and received offers was collected. We studied the initial asking dollar and equity amounts presented by the entrepreneurs, along with the financial terms of any final offers that were accepted with the angel investors. We also tracked the number of total final offers the entrepreneurs received throughout the entire negotiation process, allowing for calculations of more nuanced metrics of success.

Further, we are also concerned with various descriptive statistics on the team-level. We have several variables capturing the size and gender composition of each team (or the number of 
females present). First, we examine the angel investing success for all-female teams. That is, pitches from a team composed entirely of women. This metric also includes pitches from onewoman teams. Next, we examine teams with at least one woman, to capture the impact of a nonzero female composition on the likelihood of receiving funding and the amount funded. A team with both male and female entrepreneurs is considered a "mixed" team. We also look into statistics with all-male teams.

Next, we assess whether the Shark Tank investment process reflects that of the traditional process of securing angel financing. We find that the process on the show closely mirrors the process used by angel investors. Angel investors, similar to the investors on the show, are high net worth individuals (net worth of more than $\$ 1$ million) who invest in small companies with their own capital (Wong, Bhatia, \& Freeman, 2009). The angel investment process is a sequential one with five main stages: familiarization, screening, bargaining, managing and harvesting (Paul, Whittam, \& Wyper, 2007). Each stage in the process works as follows and is largely consistent with how Shark Tank operates.

During familiarization, investors learn details about the entrepreneur and partake in an initial meeting. The entrepreneur is required to present a business plan to allow investors to gather more information on the opportunity. Following the initial meeting, a two-step screening stage ensues. The first step is where angel investors complete due diligence on the company. The order of this step in the process differs slightly in Shark Tank, as all due diligence on the companies is performed after the investor and entrepreneur enter into a tentative agreement onair. The second step, however, is visible on Shark Tank as it is how the investor shows their commitment to the entrepreneur. The investors create an emotional attachment to the entrepreneur and company through brainstorming various ways in which they can positively 
contribute to the company beyond the initial financial investment. After follows a bargaining stage during which both parties, the entrepreneur and investor, negotiate the capital deployment and equity terms of the investment. The last two stages of the angel investing process, managing and harvesting, are not seen on Shark Tank, but nonetheless happen after a tentative deal is entered. The managing stage is after the investment capital is deployed, when investors take on an active role in the business, and through the harvesting stage, the company continues to grow. Thus, the investment process followed on Shark Tank is largely representative of that of the typical angel financing process, although time spans of processes may differ.

However, several key differences to angel investing on Shark Tank as opposed to a traditional setting are of note. First, angel investors typically do not influence one another, nor do they face direct competition for deals. On the show, however, it may be the case in which the angels begin to bid against one another and artificially skew the final company valuations upwards. Second, during the bargaining stage, entrepreneurs can, in fact, negotiate downward the dollar value of capital initially asked for in a real setting. Yet, on the show, the investor must match the dollar amount asked for by the entrepreneur in order to enter into a deal. Further, during the managing stage, the angels tend to restrict the number of business they invest in due to their hands-on approach, while investors on Shark Tank allow themselves to invest in more companies than the average angel investor.

The investment processes, both in the traditional sense and on the show, also highlight the motivations of angel investors. Typical angel investing criteria focuses on four main premises: the passion of entrepreneur, trustworthiness of entrepreneur, quality of management team, and exit opportunities (Sudek, 2008). Other principles angel investors consider include: barrier to entry of competitors, intellectual property, growth potential, competition and return on 
investment. The majority of these principles are evident in the angel investor's investment decisions on the show. The investors quantify the entrepreneur's passion through their capital investment, time allocation and concern for the coach-ability of the entrepreneur. Therefore, the angel investing process on the show is representative of the true angel financing process in all key respects.

\section{Summary Statistics}

As Table 2 indicates, our sample includes a total of 495 entrepreneurial pitches, the majority of which are by teams composed only of male entrepreneurs. Very few of the total number of pitches are from mixed teams; $60 \%$ of entrepreneurial pitches are from all-male teams, $26 \%$ from all-female teams, and $14 \%$ from mixed teams. All-female and all-male companies do not differ significantly in age, entrepreneurial team size, personal capital invested, production cost, selling price per unit or total prior company sales.

Companies are categorized into industries based on the Global Industry Classification Standard (GICS) classifications. The GICS is an industry taxonomy developed in 1999 and has been shown to result in more effective firm groupings than other industry categorizations such as the Standard Industrial Classification (SIC) system (Bhojraj, Lee, \& Oler, 2003). The GICS consists of 10 different industry sectors, ranging from consumer discretionary to information technology to utilities. However, companies may span across multiple industries. Thus, we allotted companies in multiple industries a unique industry code, modifying the initial ten GICS industry codes to include 28 variations. Figure 1 indicates the distribution of companies across all industries. Most firms are in consumer discretionary and consumer staples classifications; $78 \%$ of all companies fall into these two categories. All-female teams come from a smaller range of industries than all-male teams; all-female teams fall into 12 out of the 28 categories, while all- 
male teams span across 27 classifications, as shown in figures 2 and 3 respectively. Consumer discretionary and consumer staples industry classifications constitute $87 \%$ of all-female teams. However, for all-male teams, the concentration in consumer discretionary and consumer staples is $72 \%$. The third largest company classification for all-male teams is industrials with $4 \%$ of teams. The industry distribution for mixed teams more closely mirrors that of all-female teams, with companies falling into 10 out of the 28 categories; consumer discretionary and consumer staples comprise $84 \%$ of the companies. Not surprisingly, a Kolmogorov-Smirnov test indicates that the distribution of industries between all-female and all-male pitches is only marginally different.

\section{Insert Figures 1 to 3 here}

Where all-female and all-male teams begin to differ significantly, however, is in terms of asking valuations, including both the equity stakes and dollar value of investment. All-female teams tend to ask for lower dollar amounts of investment, with higher equity stakes, imputing lower company valuations. As shown in Table 2, the average company valuations across all teams is approximately $\$ 2.2$ million; yet, for all-male teams, the average asking valuation is closer to $\$ 3$ million, while all-female team valuations are closer to $\$ 1$ million. All-female teams ask for half the dollar amount than of that all-male teams and are also initially willing to release, on average, $2 \%$ more equity stake in their company. Despite the significantly lower valuations of all-female companies, all-male teams demonstrate lower total sales than all-female teams with more than twice the amount of personal capital invested into the companies, although these differences are not statistically significant.

We include several measures of the extensive margin, or yield rates. These include measures of the percentage of entrepreneurial pitches that received offers. Yield rates measuring 
the percentage of pitches that resulted in either at least one offer by the investors, exactly one offer, or multiple offers, indicate the following: $63 \%$ of all entrepreneurial pitches result in at least one offer by the investors. Further, this yield rate does not statistically differ between allfemale and all-male teams. Sixty-four percent of the pitches by all-female teams receive at least one offer by the investors, compared to $63 \%$ of the all-male teams. About half of the pitches that receive offers receive multiple offers. Specifically, $30 \%$ of total entrepreneurial pitches result in multiple offers. The yield rate for multiple offers is $26 \%$ for all-female teams and $30 \%$ for allmale teams. Eleven percent of the total number of teams that pitched rejected all offers they received; all-female teams had a $9 \%$ reject rate, while all-male teams had a $14 \%$ reject rate. Of the total number of teams that received at least one offer, $18 \%$ of them rejected all offers.

Furthermore, Table 2 provides descriptive statistics on the intensive margin as well, or the dollar and equity value offered (and accepted) by investors to entrepreneurs. On average, accepted deals between investors and entrepreneurs include approximately $\$ 272,000$ for $32 \%$ equity in each company. The average accepted valuation for all teams is approximately $\$ 1.3$ million. ${ }^{7}$ The majority of companies accept valuations that are lower than what they initially present, as indicated by the negative average bid ask spread in Table 2 . In order to understand the contextual background for these magnitudes taking into consideration the initial asking values, we also include final company valuations and bid-ask spreads normalized by the initial company valuations. Regardless of the gender composition of the team, on average, all teams that accept an offer walk away with around $63 \%$ of their initial asking valuation. Out of all these measures, only the average equity amount accepted statistically differs between all-female and all-male

\footnotetext{
${ }^{7}$ This value does not represent the quotient of the accepted dollar amount and the accepted equity amount. This is because the average accepted valuation for each company uses corresponding dollar and equity amounts for each company, while average dollar and average equity are calculated within each separate variable.
} 
teams. Namely, all-female teams, on average, accept offers giving a larger equity stake in the company to the investors, relative to their all-male counterparts.

\section{Insert Table 2 here}

\section{Results}

We use ordinary least-squares (“OLS”) regression analyses to calculate the relationship between gender and success in angel financing in this context. Our main dependent variables include an indicator variable equal to one if a team received at least one offer from an investor, the final company valuation a firm received, and bid ask spread (the difference between the final company valuation and initial company valuation). Additionally, we include several control variables that may influence whether investors will invest, and if so how much. These include the total number of entrepreneurs on the team, the age of the company, and prior success of the firm as measured by their total sales to date. As the final angel investment can be affected by the entrepreneur's initial company valuation, the asking dollar amount and asking equity percentage are also included as controls to mirror accuracy in the angel financing process.

Table 3 indicates the main results of our analysis, looking at the difference in outcomes between all-female and all-male teams. Model 1 examines the relationship between the gender composition of the team and the likelihood of receiving an offer. This model indicates that the likelihood of being funded is not statistically different for all-female versus all-male teams. The remaining models examine final company valuation and bid ask spread, respectively. We see in model 2 that, on average, all-female teams have a $\$ 1.2$ million higher final company valuation than all-male teams. Similarly, model 3 shows that a positive relationship exists between the 
gender composition of the team and the bid ask spread. The average bid ask spread for all-female teams is $\$ 982,000$ larger than for all-male teams due to the increased final company valuation.

\section{Insert Table 3 here}

However, prior literature indicates that women choose particular industries that tend to be less profitable (Loscocco, Robinson, Hall, \& Allen, 1991). Women-owned firms concentrate in sectors that are highly competitive, such as service and retail (Du Rietz \& Henrekson, 2000; Fairlie \& Robb, 2009). Therefore, opportunities for growth and profitability are limited within these industries. Thus, the industry in which an entrepreneur chooses to enter may have a substantial impact on the success of obtaining funding for the company, as well as the magnitude of funding received. The choice of industry may also determine the impact of the effect of having females on a team in regards to securing said funding. Therefore, we explore our prior results with the incorporation of interaction effects between the gender composition of a team and the industry to isolate the gender impact on the probability of receiving offers. We also examine the gender impact, given a certain industry, on final company valuations and bid ask spreads.

Table 4 indicates our prior main results with interaction effects incorporated between the gender composition of a team and the industry of the company. Model 1 shows that even when taking into consideration gender and industry, all-female teams are no less likely to receive offers than all-male teams. However, in model 2, it is evident that when this interaction term is taken into account, there is a negative relationship between all-female teams and final company valuations. This magnitude increases to a $\$ 3$ million difference between all-female and all-male teams. The magnitude of the interaction effect is $\$ 2.2$ million and shows the difference in the effect of an all-female team versus an all-male team in different industries. Therefore, the direct 
effect of having an all-female team and the interaction effect with industry show that all-female teams, on average, receive final company valuations that are $\$ 685,000$ lower than all-male teams.

\section{Insert Table 4 here}

Given that all-female teams receive lower final company valuations depending on the industry, we continue to examine further possibilities for an explanation. Next, we look into the differences in the initial asking dollar amount, asking equity percentage, and initial company valuation between all-female and all-male teams. Table 5 shows the relationship between the three aforementioned initial financial variables and the gender composition of the team, taking into consideration the control variables. Model 1 indicates that an all-female team, on average, has an asking dollar amount that is $\$ 130,000$ less than all-male teams. Model 2 shows that allfemale teams are initially willing to release $2.5 \%$ more equity stake in their company, therefore lowering average company valuations to $\$ 1.4$ million below that of all-male teams, as shown in model 3.

We then looked into the marginal effect of adding even one additional female to the entrepreneurial team on the initial company valuations. Table 6 indicates these results. Model 1 shows that, on average, if a female is on the team, the team asks for $\$ 110,000$ less than all-male teams. The initial equity percentage the team is willing to release is $1.2 \%$ greater than all-male teams, and initial company valuations are $\$ 1.2$ million lower than for all-male teams, as shown in models 2 and 3. Our results indicate that as long as one female is present on the team, the team initially asks for significantly less than all-male teams.

\section{Insert Tables 5 and 6 here}


Therefore, the issue lies in the internal initial company valuations for women-owned versus men-owned firms. We are unable to sufficiently assess whether all-male teams, on average, initially value their companies close to fair market value solely based on the information provided in the pitch. Such valuations would require complete analyses of the different market segments, environments, industries and competitors in the space. However, allfemale teams still value their companies at significant discounts relative to their male counterparts, holding all else except for gender constant. The lower self-valuations are the main reason for why all-female teams secure less angel financing than all-male teams. They are no less likely than male teams to receive an offer from an angel investor; however, they receive lower company valuations in the end because they ask for less initially.

\section{External Validity and Robustness}

There are several critical factors to consider when understanding the robustness of our results. The most pressing issues here include considering selection bias, determining if the environment is representative of the U.S. entrepreneurship landscape, and valuing companies when investors present final offers that have components outside of only dollar and equity stakes (“alternative company valuations").

\section{Selection bias}

Selection bias may be a problem because there is a possibility that certain companies have higher probabilities of selection for participation on the show for reasons such as the entertainment value of a pitch. Therefore, if pitches are selected based on the entertainment value they provide, this can impact two important statistics in our population - gender composition of the entrepreneurial sample and success rates of financing. 
First, we look into the correlation between entertainment value and the gender composition of a team. If it were the case that females were correlated with lower entertainment value, fewer females would successfully pass through the selection process. However, $40 \%$ of entrepreneurial teams had at least one female, including all-female and mixed teams. This percentage is substantial enough to disprove the hypothesis that female entrepreneurs are correlated with low entertainment values. Next, if female teams are associated with high entertainment values, we should see the population of female entrepreneurs larger than that of males, and much higher than where it currently stands at slightly below half the population. The entrepreneurial breakdown on the show works to prove that there is no statistically significant relationship between the entertainment value of a pitch and the gender of entrepreneurs. Therefore, the selection process for the show withstands these selection bias stress tests.

Second, we examine whether the entertainment value of a pitch and success in angel financing are correlated. If we hold true the assumptions that each company pitch is chosen based on entertainment value and those with higher entertainment value are more successful, we would witness success rates closer to that of $100 \%$. However, the rate of receiving at least one offer from the investors is only $63 \%$. This disproves that the entertainment value of a pitch is tied to, or predicts, the company's success with respect to securing funding. Consequently, we can consider the success rates to not be skewed based on the entertainment value factor.

After examining all cases of selection bias on the show with respect to entertainment values of pitches, we are confident that substantial bias in the selection process does not exist. Further, any selection bias that may be inherently present does not negatively skew our results concluded from data analysis of our sample. 


\section{Representative environment of entrepreneurship in U.S.}

Additionally, we examine whether the sample of entrepreneurs on Shark Tank is reflective of the actual population of entrepreneurs in the U.S. We do this in two ways. First, we look into the sample of entrepreneurs on the firm-level. We consider the demographic breakdown looking into all-female and mixed teams. Together, $40 \%$ of teams in the sample have at least one female entrepreneur; $26 \%$ of teams contain only females, and $14 \%$ are mixed. Out of the mixed teams, $6 \%$ were over $50 \%$ female and the rest were two-person teams of one male and one female. If an entrepreneur's percentage ownership is proportional to the percentage of presence they hold on the team, a women-owned team with regard to mixed teams in the sample, is one where there are two or more females present on the team. Thus, all-female teams and mixed teams with two or more females constitute $27 \%$ of all teams. However, based on the ownership distribution between partners on the team, mixed teams with one female and one male may also be considered women-owned. Therefore, when we consider all of the mixed and allfemale teams, the percentage increases to $40 \%$ of the sample. As a comparison, in the U.S. in 2012, 36\% of all businesses were women-owned (U.S. Census Bureau, 2012). Thus, regardless of how we consider mixed teams, the representative proportion of women-owned firms in the sample is close to the one in the U.S, as both $27 \%$ and $40 \%$ are near $36 \%$, and all are well below the majority.

Second, we examine whether the sample of entrepreneurs is reflective of that in the U.S. on the entrepreneur-level. Thirty-five percent of all of the entrepreneurs in the sample were female - there were 255 females out of 734 entrepreneurs. In 2014, 37\% of new entrepreneurs in the U.S. were female (Fairlie, Morelix, Reedy, \& Russell, 2015). Thus, the percent of female entrepreneurs in our sample is directly in line with that in the U.S. Therefore, given our analysis 
of the entrepreneurial sample both on the firm-level and the entrepreneur-level, we conclude this sample is representative of the larger entrepreneurial population in the U.S.

\section{Alternative Company Valuations}

In the main analysis, we chose to exclude from our financial analyses certain teams whose final company valuations consisted of clauses outside of only dollar and equity amounts. The investors have the opportunity to present entrepreneurs with offers that contain royalty contingencies; around $10 \%$ of teams received such an offer. As this is a small percentage of the total population, these teams were removed from financial metric analyses such as the final company valuations and bid ask spreads. The teams are still included in calculations for all other variables that did not consider final company valuations. This is due to the subjective nature of how angel investors value dollar and royalty amounts in response to a final company valuation. Royalties are typically valued using the present value of the notional royalty stream that ownership relieves the business from paying. The capital value of the asset is then calculated using either a discounted cash flow or multiple to arrive at the current value of the forecast notional royalty stream (Liberman, Chrocziel, \& Levine, 2011). As proper discount rates and multiples for each company cannot be determined given the provided information, we cannot accurately forecast future sales in order to arrive at the fair company valuation. However, such royalty offers are beneficial for both the angel investors and entrepreneurs. They leave entrepreneurs with more equity due to the risk mitigation for the lender in comparison to a traditional equity investment in the company. If the business and sales grow rapidly, the angel's royalty payments will allow for an earlier return on investment, as opposed to stock in the company. Thus, the angel will be willing to accept a smaller equity stake in return for the royalty stream. Royalty-structured offers further prevent dilution of business ownership, while returning 
the upfront capital needed to jumpstart the business. Therefore, exclusion of this cohort of pitches does not significantly affect our results.

\section{Discussion and Conclusions}

This paper investigates the relationship between success rates in angel financing and the gender of entrepreneurs in a sample environment covering nearly 500 U.S. entrepreneurial teams. Our results show that no bias exists in the likelihood of receiving such funding between female and male entrepreneurs. Rather, we find the disparities lie in the magnitude of final capital received, as women-owned firms receive less funding from angel investors than their male counterparts. Women-owned firms, depending on industry, receive company valuations that are $\$ 685,000$ less than those of all-male firms. These differences remain statistically significant even if only one female is present on the team, controlling for numerous firm and entrepreneurial characteristics we believe may impact the company valuations. However, these differences are due to the fact that women-owned firms ask for less and value their own companies at significantly lower levels than all-male firms.

Further research should examine more closely the panel of angel investors present for each pitch. Entrepreneurs can establish commonalities with the angel investors, such as ones based on gender, familial and educational backgrounds, or interests. Such commonalities lead to homophily, the sociological principle that contact between similar people occurs at higher rates than among dissimilar people (McPherson, Smith-Lovin, \& Cook, 2001). These established commonalities may also affect financing because the investors may be more likely to fund certain entrepreneurs over others. Namely, is it more likely female entrepreneurs receive angel funding from female investors? The commonalities between entrepreneurs and investors can impact company valuations, depending on the importance they hold for angel investors. Thus, 
further research can benefit from examining the rates of commonalities for all-male teams versus all-female teams and the impact on the likelihood of receiving offers, the magnitude of final company valuations and bid ask spreads. As our dataset allows for such analyses to be performed, it is our intent to continue to investigate more possibilities that can work to explain the disparities in angel financing for firms. Further analyses will take into account other commonalities outside of gender, such as similar familial backgrounds or interests, to see how they impact the likelihood of angel funding.

Our results provide insights for entrepreneurs and policy makers for overcoming the funding differences between male- and female-led companies. Prior to seeking angel financing, it is crucial for entrepreneurs to understand how to establish fair company valuations given current market conditions and other firms in the space. Our findings help inform female entrepreneurs about the significant differences in initial company valuations between all-female and all-male teams. Further, our results stress the importance of providing proper company valuations in order to better access the vital funding needed for women-owned ventures in the early stages. However, it may be the case that the differences in initial company valuations occur because they reached a partial equilibrium result. Perhaps, women are asking for less because in this equilibrium, they understand they will not receive funding if they ask for more initially. Nevertheless, this is also where government policy can be of large assistance.

For policy makers, the results suggest that providing incentives, such as government tax considerations, to angel investors who fund new female-owned entrepreneurial ventures may be an impactful way of minimizing the gender financing gap. One such government program already in existence is the Small Business Innovation Research (SBIR) program, which encourages domestic small businesses to engage in federal research and development (SBIR, 
2016). However, SBIR only focuses on small firms in the technology sector. A similar program and idea structure can be taken and applied to private investors that fund new women-owned businesses in numerous industries, and industries outside of where women tend to cluster. Instead of awarding private investors grants, they can receive tax reliefs that may be tied to either the magnitude of the funding they provide for female-owned ventures or the number (percentage) of female-owned ventures they fund. Regardless, various policies can be put into effect that would encourage angel investors to fund more women-owned businesses with larger capital amounts, given that all-female teams come with valuations closer to that of all-male teams. The increase in available funding for women-owned ventures in numerous market sectors can encourage more females to start companies and enter industries that were previously maledominated. 


\section{References}

ABC. (2016). Apply to Shark Tank - Casting. ABC Television Network. Retrieved from http://abc.go.com/shows/shark-tank/apply

Alsos, G. A., Isaksen, E. J., \& Ljunggren, E. (2006). New venture financing and subsequent business growth in men- and women-led businesses. Entrepreneurship theory and practice, 30, 667-686.

Amatucci, F. M., \& Sohl, J. E. (2004). Women entrepreneurs securing business angel financing: Tales from the field. Venture Capital, 6(2-3), 181-196.

Amit, R., Glosten, L., \& Muller, E. (1990). Entrepreneurial ability, venture investments, and risk sharing. Management science, 36, 1233-1246.

Becker-Blease, J. R., \& Sohl, J. E. (2007). Do women-owned businesses have equal access to angel capital? Journal of Business Venturing, 22, 503-521.

Berger, A. N., \& Udell, G. F. (1998). The economics of small business finance: The roles of private equity and debt markets in the financial growth cycle. Journal of Banking \& Finance, 22, 613-673.

Bhojraj, S., Lee, C., \& Oler, D. (2003). What's my line? A comparison of industry classification schemes for capital market research. Journal of Accounting and Economics 41, 745-769.

Brooks, A. W., Huang, L., Kearney, S. W., \& Murray, F. E. (2014). Investors prefer entrepreneurial ventures pitched by attractive men. Proceedings of the National Academy of Sciences, 111, 4427-4431.

Brush, C., Carter, N., Gatewood, E., Greene, P., \& Hart, M. (2004). Clearing the hurdles: Women building high-growth businesses. FT Press.

Buttner, E. H., \& Rosen, B. (1989). Funding new business ventures: Are decision makers biased against women entrepreneurs? Journal of Business Venturing, 4, 249-261.

Buttner, E. H., \& Rosen, B. (1992). Rejection in the loan application process: Male and female entrepreneurs' perceptions and subsequent intentions. Journal of Small Business Management, 30, 58.

Carter, N., Brush, C., Greene, P., Gatewood, E., \& Hart, M. (2003). Women entrepreneurs who break through to equity financing: the influence of human, social and financial capital. Venture Capital: an international journal of entrepreneurial finance, 5, 1-28.

Coleman, S. (2000). Access to capital and terms of credit: A comparison of men-and womenowned small businesses. Journal of Small Business Management, 38, 37.

Coleman, S., \& Robb, A. (2009). A comparison of new firm financing by gender: evidence from the Kauffman Firm Survey data. Small Business Economics, 33, 397-411.

Competitiveness, C. (2007). Competitiveness Index, Where America Stands. Washington DC: Council of Competitiveness.

Du Rietz, A., \& Henrekson, M. (2000). Testing the female underperformance hypothesis. Small Business Economics, 14(1), 1-10.

Fairlie, R. W., \& Robb, A. M. (2009). Gender differences in business performance: evidence from the Characteristics of Business Owners survey. Small Business Economics, 33, 375395.

Fairlie, R. W., Morelix, A., Reedy, E. J., \& Russell, J. (2015). The Kauffman Index 2015: Startup Activity| National Trends.

Fay, M., \& Williams, L. (1993). Gender bias and the availability of business loans. Journal of Business Venturing, 8, 363-376. 
Greene, P. G., Brush, C. G., Hart, M. M., \& Saparito, P. (2001). Patterns of venture capital funding: is gender a factor? Venture Capital: An international journal of entrepreneurial finance, 3, 63-83.

Gundry, L. K., \& Welsch, H. P. (2001). The ambitious entrepreneur: High growth strategies of women-owned enterprises. Journal of business Venturing, 16, 453-470.

Lerner, J. (1998). "Angel” financing and public policy: An overview. Journal of Banking \& Finance, 22(6), 773-783.

Liberman, A., Chrocziel, P., \& Levine, R. (2011). International Licensing and Technology Transfer: Practice and the Law. Wolters Kluwer Law \& Business.

Loscocco, K. A., Robinson, J., Hall, R. H., \& Allen, J. K. (1991). Gender and small business success: An inquiry into women's relative disadvantage. Social forces, 70(1), 65-85.

McPherson, M., Smith-Lovin, L., \& Cook, J. M. (2001). Birds of a feather: Homophily in social networks. Annual review of sociology, 415-444.

Paul, S., Whittam, G., \& Wyper, J. (2007). Towards a model of the business angel investment process. Venture Capital, 9(2), 107-125.

Preston, S. L. (2004). Angel investment groups, networks, and funds: A Guidebook to developing the right angel organization for your community. Ewing Marion Kauffman Foundation.

SBIR. (2016). The SBIR Program. SBIR / STTR: America's Seed Fund Powered by SBA. Retrieved from https://www.sbir.gov/

Shane, S. (2012). The importance of angel investing in financing the growth of entrepreneurial ventures. The Quarterly Journal of Finance, 2(02), 1250009.

Sudek, R. (2007). Angel Investment Criteria. Journal of Small Business Strategy, 17(2), 89-103.

Wong, A., Bhatia, M., \& Freeman, Z. (2009). Angel finance: the other venture capital. Strategic change, 18(7-8), 221-230.

U.S. Census Bureau (1997). 1997 Survey of Women-Owned Enterprises Company Statistics Series. Washington, D.C.: USGPO.

U.S. Census Bureau (2002). 2002 Survey of Business Owners (SBO), Women-owned firms Company Statistics Series. Washington, D.C.: USGPO.

U.S. Census Bureau. (2007). 2007 Survey of Business Owners (SBO) Company Statistics Series. Washington, D.C.: USGPO.

U.S. Census Bureau. (2012). 2012 Survey of Business Owners (SBO) Company Statistics Series. Washington, D.C.: USGPO.

U.S. Department of Commerce. (2010). Women-Owned Businesses in the $21^{\text {st }}$ Century. Economics and Statistics Administration. Washington, D.C.: USGPO. 


\section{Appendices}

Appendix A: Details on the television show selection process

There are two main ways to apply to be on the show: through an email submission or an open call. The first, an email submission, requires that the entrepreneur email their name, age, contact information, a recent photo of themselves and a brief non-confidential description of their business, product or idea to a general casting email. The second option is to attend an open call audition. These auditions are held on numerous dates every season across the U.S. During the open call, entrepreneurs are given the opportunity to do a 1-minute pitch of their business/product/idea to a member of the casting team. However, the entrepreneurs must have the application packet completed prior to their arrival. The application packet consists of extensive paper work that detail their business/product/idea and financials. All open calls are open to the general public, as long as the entrepreneurs arrive during the allotted two-hour timeslot when numbered wristbands are distributed (ABC, 2016). Only the applicants with numbered wristbands are guaranteed to have a chance to pitch, or approximately the first 500 applicants. 
Figure 1. Industry Distribution for All Teams

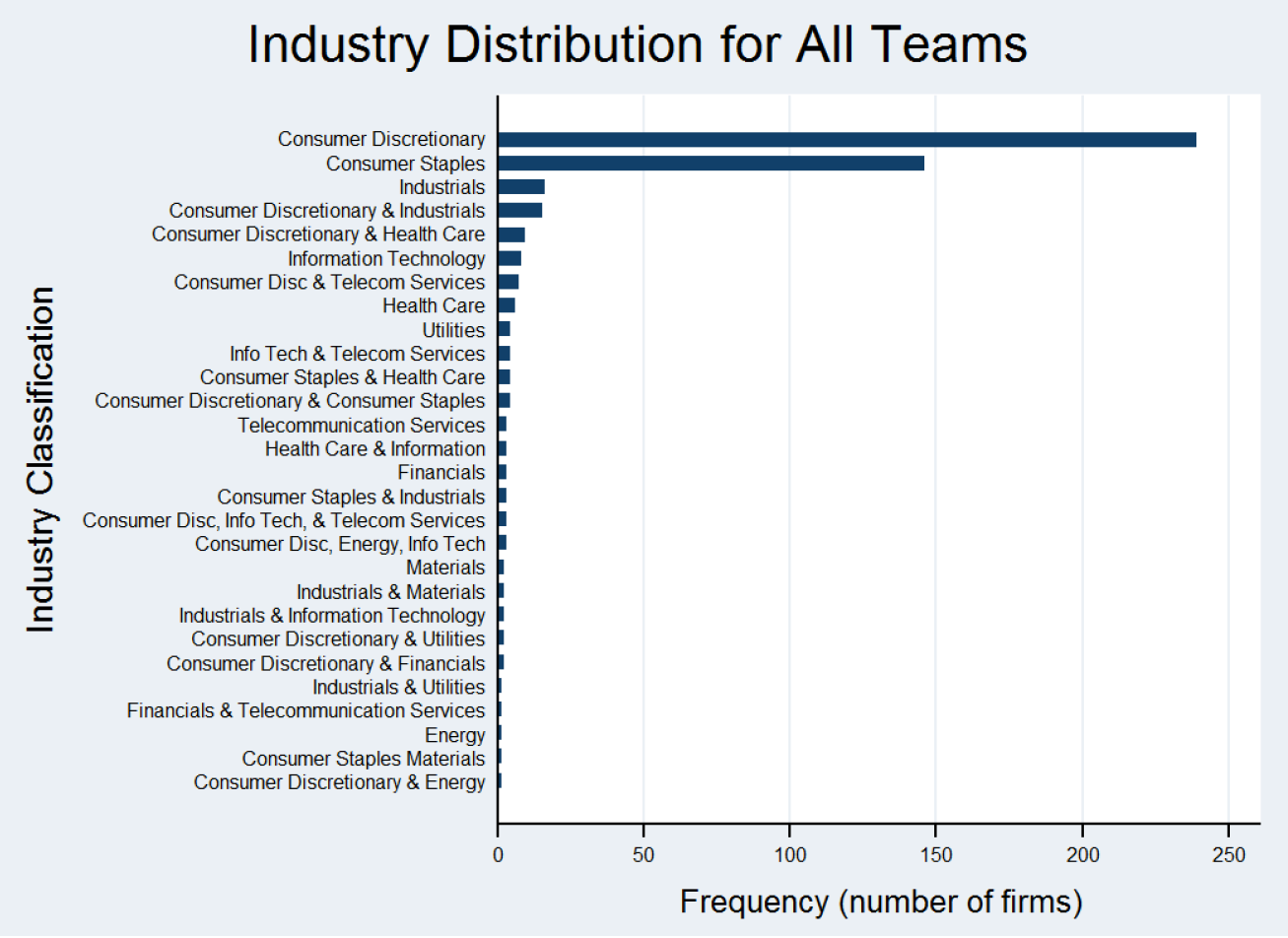

Figure 2. Industry Distribution for All-Female Teams

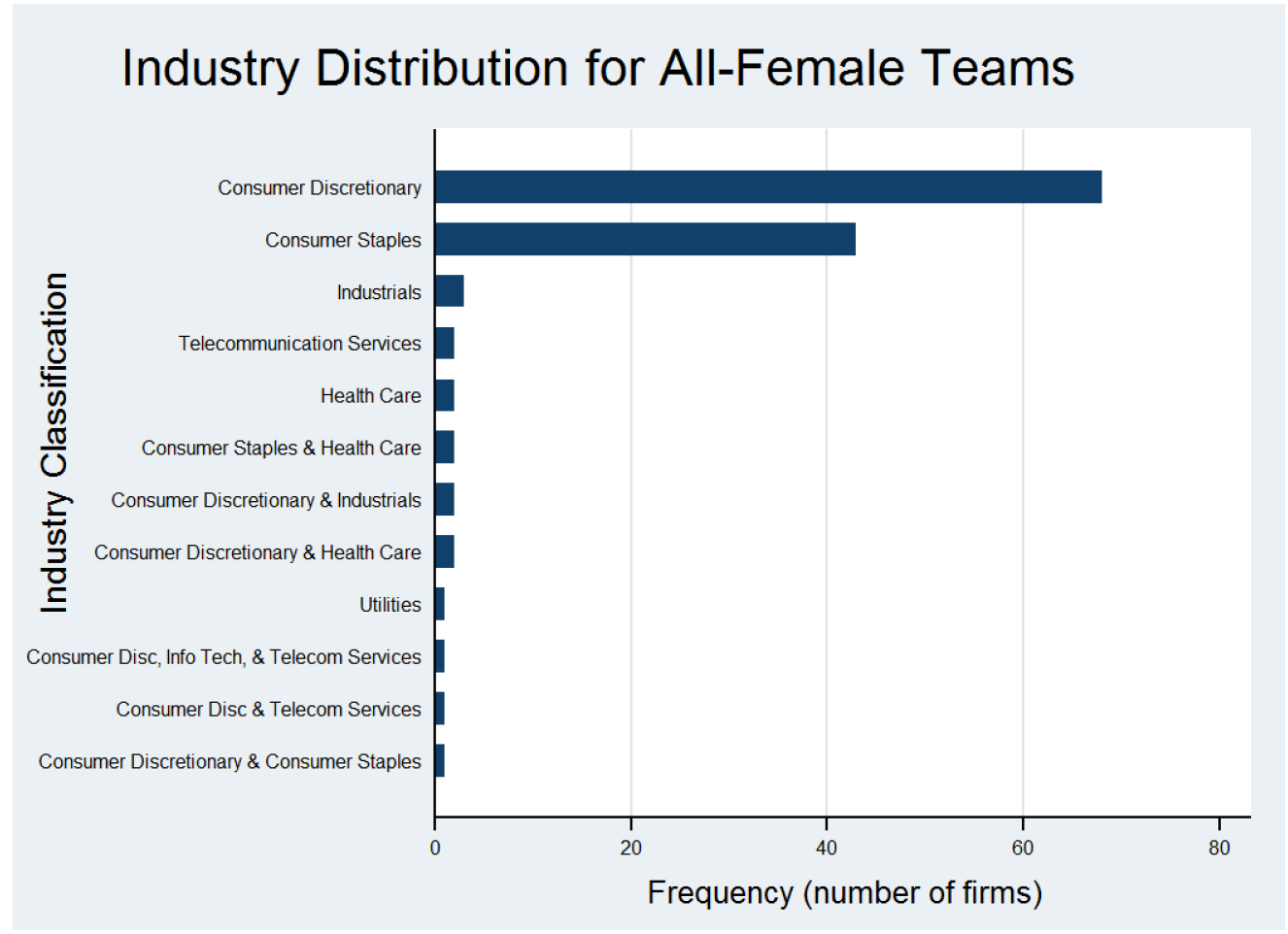


Figure 3. Industry Distribution for All-Male Teams

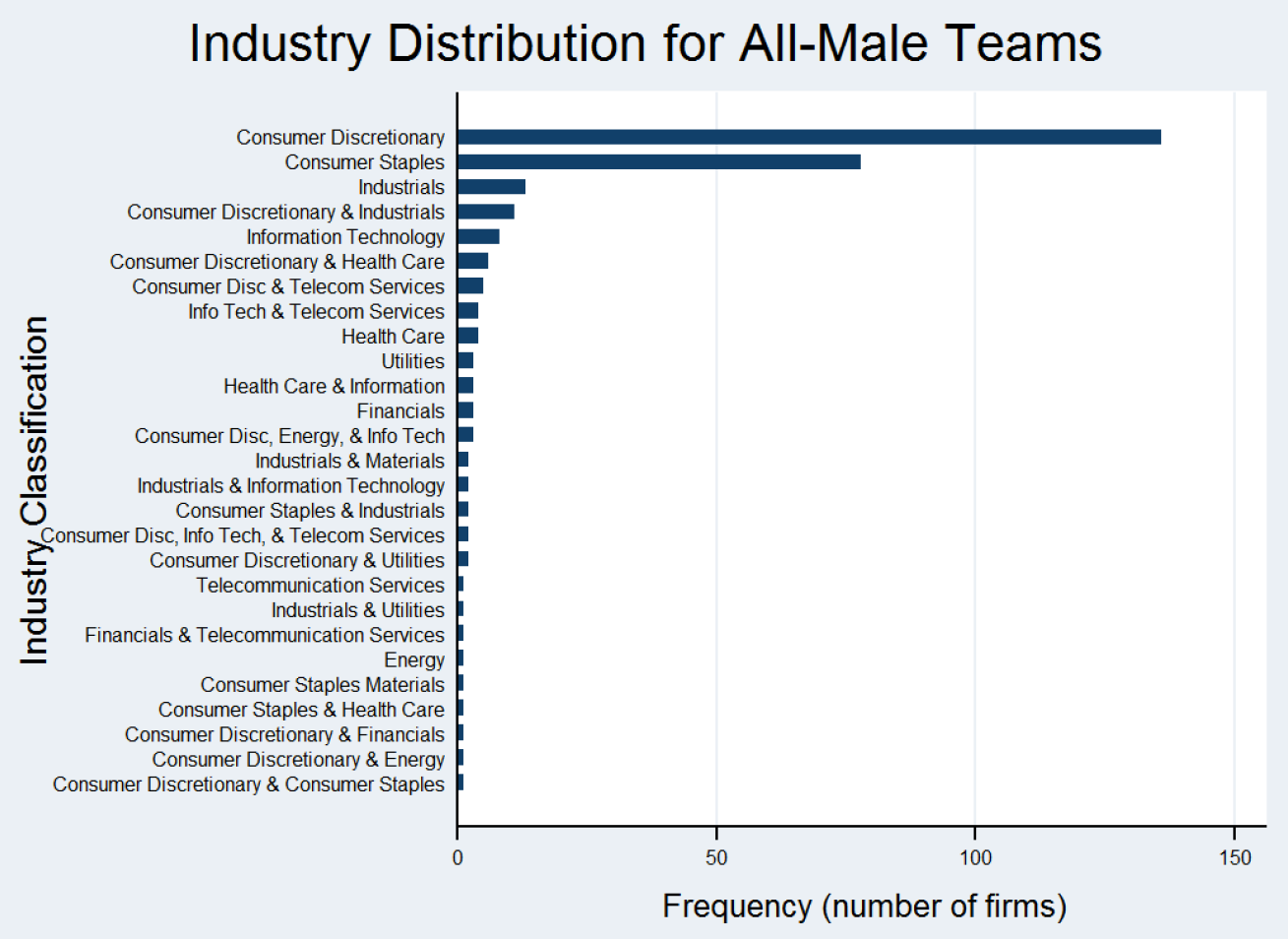


Table 1. U.S. non-farm firms by gender ownership, 1997 to 2012

All firms ${ }^{\mathrm{a}}$

(number)

All U.S. firms

$2012^{\mathrm{b}}$

$27,626,360$

$2007^{\mathrm{c}}$

$27,092,908$

$2002^{\mathrm{d}}$

$22,974,655$

$1997^{\mathrm{e}}$

$20,821,934$

Growth 1997-2012 (\%)

Women-owned firms

2012

$9,878,397$

2007

$7,792,115$

2002

$6,489,259$

1997

$5,417,034$

Growth 1997-2012 (\%)

82.4

a. Number of firms with or without paid employees

b. 2012 Survey of Business Owners

c. 2007 Survey of Business Owners

d. 2002 Survey of Business Owners, Women-owned firms

e. 1997 Survey of Women-Owned Business Enterprises 
Table 2. Descriptive statistics of sample of entrepreneurial pitches

\begin{tabular}{lccc}
\hline & $\begin{array}{c}(\mathbf{1}) \\
\text { All } \\
\text { teams }\end{array}$ & $\begin{array}{c}(\mathbf{2}) \\
\text { All-female } \\
\text { teams }\end{array}$ & $\begin{array}{c}\text { (3) } \\
\text { All-male } \\
\text { teams }\end{array}$ \\
\hline & & & \\
Number of pitches & 495 & 128 & 296 \\
Number of offers & 515 & 129 & 308 \\
Maximum number of offers & 5 & 5 & 4
\end{tabular}

Dependent Variables

Extensive margin

Yield rates**

At least one offer

One offer only

$63 \% \quad 64 \% \quad 63 \%$

Multiple offers

$33 \%$

$38 \%$

$32 \%$

Accepted offer

$30 \%$

$26 \%$

$30 \%$

Rejected offer

$51 \%$

$55 \%$

$49 \%$

$11 \%$

$9 \%$

$14 \%$

Intensive margin

Average dollar amount accepted

Average equity amount accepted

Average accepted company valuation

Average accepted company valuation (normalized)

Average bid-ask spread

Average bid-ask spread (normalized)

\begin{tabular}{|c|c|c|}
\hline$\$ 272,545$ & $\$ 197,232$ & $\$ 318,000$ \\
\hline $32 \%$ & $37 \%$ & $31 \%$ \\
\hline$\$ 1,250,153$ & $\$ 827,454$ & $\$ 1,450,838$ \\
\hline 0.64 & 0.63 & 0.63 \\
\hline$-\$ 812,071.60$ & $-\$ 581,070.60$ & $-\$ 961,297.80$ \\
\hline-0.36 & -0.37 & -0.37 \\
\hline
\end{tabular}

\section{Control Variables}

Industry composition****

Consumer discretionary

Consumer staples

Energy

Financial services

Health Care

Industrials

Information Technology

Materials

Telecommunication Services

Utilities

Asking dollar amount

Asking equity amount

Asking company valuation

Average team size

$\begin{array}{cccc}239 & 68 & 136 & \\ 146 & 43 & 78 & \\ 1 & 0 & 1 & \\ 3 & 0 & 3 & \\ 6 & 2 & 4 & \\ 16 & 3 & 13 & \\ 8 & 0 & 8 & \\ 2 & 0 & 0 & \\ 3 & 2 & 1 & \\ 4 & 1 & 3 & \\ \$ 259,855 & \$ 159,906 & \$ 320,253 & * * * \\ 18 \% & 19 \% & 17 \% & * * * \\ \$ 2,166,046 & \$ 1,323,934 & \$ 2,655,928 & * * * \\ 1.48 & 1.38 & 1.37 & \end{array}$


Total sales

Production cost per unit

Price per unit

Company age (years)

Personal capital invested

$\begin{array}{ccc}\$ 782,514 & \$ 894,291 & \$ 703,097 \\ \$ 148 & \$ 16 & \$ 264 \\ \$ 443 & \$ 71 & \$ 773 \\ 2.34 & 2.18 & 2.13 \\ \$ 292,921 & \$ 159,668 & \$ 407,906\end{array}$

* Note: Column 1 includes descriptive statistics for all teams, including all male, all female, and teams with mixed-composition of male and female. All-female teams (column 2) are those entrepreneurial teams with only female members, similarly for all-male teams (column 3). Normalized values are calculated by dividing by initial company valuation. Average accepted company valuation is not the product of average dollar amount and equity. This is because the valuation for each company uses corresponding dollar and equity amounts for each company, while average dollar and average equity are calculated within each separate variable.

** Yield rates are calculated based on the total number of entrepreneurial pitches in that category. For instance, yield rates for column 1 consider the number of offers of each type divided by the total number of pitches by all teams (all-female, all-male and mixed). Yield rates in column 2 indicate the total number of offers of each type divided by the number of all-female teams.

*** indicates the t-test of means between all-female and all-male entrepreneurial teams is significantly different at the $5 \%$ level.

**** We categorize industries using the Global Industry Classification System (GICS). Consumer discretionary includes automobiles, consumer durables and apparel, consumer services, media, retail. Consumer staples include food and beverage, tobacco, household and personal products. Financial services include banks, insurance and real estate. Health care includes healthcare equipment and services, pharmaceuticals, and biotechnology. Industrials include capital goods, commercial and professional services, and transportation. Information technology includes software and software-related services, technology hardware and equipment, and semiconductors and semiconductor equipment. 
Table 3. The relationship between all-female teams and success measure outcomes for angel financing

(1) (2)

(2) (3)

\begin{tabular}{lccc} 
Variables & Offer & Final Company Valuation & Bid-Ask Spread \\
\hline & & & \\
Female Team & 0.002 & $1,193,898.585^{*}$ & $982,047.761^{*}$ \\
Total \# Entrepreneurs & {$[0.070]$} & {$[656,184.973]$} & {$[549,406.584]$} \\
& 0.075 & $871,238.155^{*}$ & $877,692.814^{* *}$ \\
Industry & {$[0.055]$} & {$[485,141.827]$} & {$[406,196.614]$} \\
& -0.006 & $21,131.615$ & $53,566.799$ \\
Company Age & {$[0.005]$} & {$[50,526.375]$} & {$[42,304.418]$} \\
& -0.015 & $-40,367.767$ & $28,159.429$ \\
Total Sales To Date & {$[0.017]$} & {$[164,049.402]$} & {$[137,354.291]$} \\
& -0.000 & $-0.178^{*}$ & $-0.162^{*}$ \\
Asking Dollar Amount & {$[0.000]$} & {$[0.100]$} & {$[0.084]$} \\
& -0.000 & $6.932^{* * *}$ & $-2.612^{* * *}$ \\
Asking Equity Percentage & {$[0.000]$} & {$[0.764]$} & {$[0.640]$} \\
& $-0.009 * *$ & $-83,039.527^{* *}$ & $27,439.474$ \\
Constant & {$[0.003]$} & {$[38,285.690]$} & {$[32,055.611]$} \\
& $0.772 * * *$ & $-375,116.502$ & $-2,287,769.359^{* *}$ \\
Observations & {$[0.121]$} & {$[1,253,911.562]$} & {$[1,049,867.487]$} \\
Adjusted R-squared & 215 & 106 & 106 \\
\hline
\end{tabular}

Standard errors in brackets $* * * \mathrm{p}<0.01, * * \mathrm{p}<0.05, *$ $\mathrm{p}<0.1$

*Note: Model (1) dependent variable is binary; "Offer" is equal to one for teams that received at least one offer and equal to zero for teams that received no offers. 
Table 4. The relationship between all-female teams and success measure outcomes for angel financing taking into consideration interaction effects

\begin{tabular}{|c|c|c|c|}
\hline & (1) & (2) & (3) \\
\hline Variables & Offer & $\begin{array}{l}\text { Final Company } \\
\text { Valuation }\end{array}$ & Bid-Ask Spread \\
\hline \multirow{2}{*}{ Female Team } & 0.063 & $-2,914,479.838 * * *$ & $-2,435,249.571 * * *$ \\
\hline & {$[0.083]$} & {$[672,978.451]$} & {$[566,461.443]$} \\
\hline \multirow[t]{2}{*}{ Female Team * Industry } & -0.024 & $2,229,307.430 * * *$ & $1,854,309.791 * * *$ \\
\hline & {$[0.018]$} & {$[250,617.809]$} & {$[210,950.775]$} \\
\hline \multirow[t]{2}{*}{ Total \# Entrepreneurs } & 0.076 & $576,279.716$ & $632,350.107 * *$ \\
\hline & {$[0.055]$} & {$[363,401.110]$} & {$[305,883.074]$} \\
\hline \multirow[t]{2}{*}{ Industry } & -0.004 & $-22,902.562$ & $16,939.726$ \\
\hline & {$[0.006]$} & {$[38,013.188]$} & {$[31,996.574]$} \\
\hline \multirow[t]{2}{*}{ Company Age } & -0.014 & $22,992.250$ & $80,861.492$ \\
\hline & {$[0.017]$} & {$[122,577.608]$} & {$[103,176.392]$} \\
\hline \multirow[t]{2}{*}{ Total Sales to Date } & -0.000 & -0.099 & -0.096 \\
\hline & {$[0.000]$} & {$[0.075]$} & {$[0.063]$} \\
\hline \multirow[t]{2}{*}{ Asking Dollar Amount } & -0.000 & $6.574 * * *$ & $-2.910 * * *$ \\
\hline & {$[0.000]$} & {$[0.571]$} & {$[0.481]$} \\
\hline \multirow[t]{2}{*}{ Asking Equity Percentage } & $-0.009 * *$ & $-72,957.682 * *$ & $35,825.426$ \\
\hline & {$[0.003]$} & {$[28,581.185]$} & {$[24,057.441]$} \\
\hline \multirow[t]{2}{*}{ Constant } & $0.763 * * *$ & $52,297.022$ & $-1,932,252.183 * *$ \\
\hline & {$[0.120]$} & {$[936,572.098]$} & {$[788,334.279]$} \\
\hline Observations & 215 & 106 & 106 \\
\hline Adjusted R-squared & 0.038 & 0.712 & 0.588 \\
\hline
\end{tabular}

Standard errors in brackets

$* * * \mathrm{p}<0.01, * * \mathrm{p}<0.05, * \mathrm{p}<0.1$

*Note: Model (1) dependent variable is binary; "Offer" is equal to one for teams that received at least one offer and equal to zero for teams that received no offers. 
Table 5. The relationship between all-female teams and initial asking valuations

\begin{tabular}{llll}
\hline & $(1)$ & $(2)$ & $(3)$ \\
Variables & Asking Dollar & Asking Equity & Initial Company Valuation \\
\hline & & & \\
Female Team & $-130,058.317^{* *}$ & $2.481^{*}$ & $-1,378,930.863^{* *}$ \\
Total \# Entrepreneurs & {$[54,727.889]$} & {$[1.380]$} & {$[632,373.268]$} \\
& $-25,096.261$ & -1.270 & $43,016.386$ \\
Industry & {$[43,174.998]$} & {$[1.088]$} & {$[498,881.194]$} \\
& $8,830.526^{* *}$ & -0.163 & $77,457.417$ \\
Company Age & {$[4,178.701]$} & {$[0.105]$} & {$[48,284.317]$} \\
& $-14,073.948$ & $1.557 * * *$ & $-275,095.705^{*}$ \\
Total Sales To Date & {$[12,713.271]$} & {$[0.321]$} & {$[146,900.110]$} \\
& $0.050 * * *$ & $-0.000^{* * *}$ & $0.514 * * *$ \\
Constant & {$[0.009]$} & {$[0.000]$} & {$[0.106]$} \\
& $285,471.509^{* * * *}$ & $15.521^{* * *}$ & $2,643,320.904 * * *$ \\
Observations & {$[82,151.800]$} & {$[2.071]$} & {$[949,252.801]$} \\
Adjusted R-squared & & & \\
\hline
\end{tabular}

Standard errors in brackets

$* * * \mathrm{p}<0.01, * * \mathrm{p}<0.05, * \mathrm{p}<0.1$

*Note: Model (1) dependent variable is binary; "Offer" is equal to one for teams that received at least one offer and equal to zero for teams that received no offers. 
Table 6. The relationship between female (all-female and mixed) teams and initial asking valuations

(1)

Variables

Female and Mixed Teams

Total \# Entrepreneurs

Industry

Company Age

Total Sales To Date

Constant

Asking Dollar

$-110,159.361^{* *}$

$[45,352.212]$

$-13,174.891$

$[37,820.240]$

$8,870.502 * *$

[3,638.649]

$-10,152.255$

$[9,879.829]$

$0.049^{* * *}$

[0.008]

$261,014.119^{* * *}$

$[68,961.272]$
(2)

Asking Equity

(3)

Initial Company Valuation

1.156

[1.204]

$-2.233^{* *}$

[1.004]

$-0.224 * *$

[0.097]

$1.119^{* * *}$

[0.262]

$-0.000 * * *$

[0.000]

$18.035^{* * *}$

[1.831]
$-1,195,554.617 * *$

[527,968.661]

$177,572.961$

[440,285.061]

$81,903.869^{*}$

[42,359.405]

$-213,509.631^{*}$

[115,016.224]

$0.529 * * *$

[0.095]

$2,296,606.605^{* * *}$

[802,814.003]

Observations

254

254

254

Adjusted R-squared

0.154

0.109

0.126

Standard errors in brackets

*** $\mathrm{p}<0.01,{ }^{* *} \mathrm{p}<0.05,{ }^{*} \mathrm{p}<0.1$

*Note: Model (1) dependent variable is binary; "Offer" is equal to one for teams that received at least one offer and equal to zero for teams that received no offers. 